\title{
Investigation of some properties of gluten-free tarhanas produced by red, green and yellow lentil whole flour
}

\author{
Ali GÖNCÜ (D), İlyas ÇELİK
}

\begin{abstract}
Gluten-free lentil tarhanas were obtained by replacing red, green and yellow lentil whole flour instead of wheat flour used in traditional tarhana formulation. Some physical, chemical, bioactive, microbiological, reological, morphological and sensory properties of these tarhanas were investigated comparatively. Amount of crude protein (\%), crude ash (\%), crude fat(\%), soluble-insoluble-total dietary fibre (\%), some elements, antioxident activity ( $\mu \mathrm{mol} \mathrm{TE} / 100 \mathrm{~g})$ and total phenolic content (mg GAE/100g) of the tarhanas which were obtained by using lentil flour were significantly increased compared to the control tarhanas. All varieties of tarhana exhibited pseudoplastic flow behavior. In terms of microbiological evaluation; lentil tarhanas has higher lactic acid bacteria with yeast and mold amount compared to control tarhanas. When lentil tarhanas were compared, the green lentil tarhanas is the richest one according to the values of soluble-insoluble-total dietary fiber (\%), crude ash (\%),total phenolic content and antioxidant activity. Tarhanas examined by scanning electron microscopy (SEM), the control and red lentil tarhanas with green and yellow lentil tarhanas exhibited similar morphological characteristics. It has been found that the sensory evaluation of tarhanas is not statistically different from each other in terms of general appreciation. As a result of this, it shows that gluten-free tarhanas produced with lentil flour can be consumed instead of control tarhanas.
\end{abstract}

Keywords: gluten-free; tarhana; red lentil; green lentil; yellow lentil.

Practical Application: Tarhana soup, which is a traditional Turkish food, was produced in the production of legumes without gluten. Produced products are very important for individuals with being celiac disease and gluten susceptibility. Moreover, according to the results, it would be more beneficial to consume it instead of traditional tarhana because it causes increases in the food composition.

\section{Introduction}

Cereals supply significant amounts of energy, protein and some elements in human diets (Dordević et al., 2010). However, celiac patients cannot consume gluten-containing grains. Celiac disease is a genetic disorder in individuals who have intolerance to gluten in wheat, barley and rye (Pietzak et al., 2001; Dewar et al., 2004). Rye and barley prolamines and gluten from wheat cause abnormal reactions of these individuals' immune systems (Jnawali et al., 2016). Legumes are also an important part of the human diet as a source of protein, vitamins, minerals, dietary fibre and bioactive components (Amarowicz \& Pegg, 2008; Derbyshire, 2011; Magalhães et al., 2017; Ozdemir et al., 2019). The food processing industry is exploring new usage possibilities; either alone or in combination with other food sources, when producing food products due to the healthy components of legumes. Thus, it is aimed to increase the consumption of legumes (Aguilera et al., 2011; Derbyshire, 2011). According to Turkish Standards (TS NO: 143) (Anonymous, 2008), shelled lentils; Lens esculenta of the legumes (Leguminosae) family is defined as dried grains of cultivated plants belonging to Moench (Lens culinaris, Medic). Lentil varieties are consisted of yellow, green, red, brown and black with a wide range of different colors but approximately $80 \%$ of the world's consumption of lentils belongs to red lentils (Asif et al., 2013). A lentil grain has many benefits proven by scientific studies on human health. It is an important nutritional source which can be used as a functional ingredient due to the prebiotic properties of the fibers contents, dietary fiber contents and supporting the digestive system with its high protein content. Especially with its fiber content, it has functions such as lowering blood sugar, protecting against cardiovascular diseases, cancer and regulating the digestive system (Wang, 2008).

Fermented foods were composed of an important part of diets in the world. Tarhana, as a fermented product is consumed heavily by most people in Turkey. Tarhana was acquired from mixing wheat flour, yoghurt, yeast and various vegetables and spices (tomatoes, red peppers, onions, mint, salt, etc.); fermented for a few days, then dried and milled (Anonymous, 1981; Temiz \& Yılmazer, 1998; Daglioglu, 2000; Ibanoğlu \& Maskan, 2002; Celik et al., 2005; Sengun et al., 2009; Settanni et al., 2011; Koca et al., 2017). Also tarhana like products were found in various countries. These are; "kishk" in Egypt, Syria and Jordan, "trahana" in Greece, "turkhana" in Bulgaria, "kushuk" in Iraq and Iran, "tahonya/talkuna" in Hungary and Finland and "tarana" in Serbia (Ibanoğlu et al., 1999; Yildirim \& Ercan, 2004). Tarhana is an acidic and sour taste with a strong aroma and can be prepared by diluting to make soup. It is a good source of protein, vitamins 
and minerals. Because of this, it is widely used in nutrition of children and the old people (Daglioglu, 2000; Celik et al. 2005).

It was thought that lentil, which has rich components in food, can be used in tarhana production to increase consumption and develop a new gluten-free food product. Also, lentil and tarhana, two of the most consumed soup types, were aimed to be gathered together with this product. Thus, in this study, by using red, yellow and green lentil types instead of wheat flour, producing the products; its physico-chemical, microbiological, morphological and sensory properties were examined.

\section{Materials and methods}

\subsection{Materials}

Red, green and yellow lentil whole flours and wheat flour with other raw materials (tomato, red pepper, onion, dried mint, yoghurt, yeast and salt) were supplied by being purchased from the local markets of Denizli/TURKEY. The yoghurt used is full fat (at least 3.5\% fat) and set-style made of cow's milk. The yeast is used compressed baker's yeast in wet form (Saccharomyces cerevisiae).

\subsection{Tarhana production}

In this study, control tarhana (CT) was traditionally produced using wheat flour. Lentil tarhanas were produced using red (RLT), green (GLT) and yellow (YLT) lentil flour. Formulations given in Table 1 were used for tarhana production. The formulations were determined by preliminary experiments in the laboratory.

Tarhanas were produced by modifying Çelik et al. (2010) method. Onions, tomatoes, and red peppers to be used in tarhana production were boiled separately in stainless steel pot and allowed to cool for 10 minutes at room temperature. Then they were drawn into the mash (Arzum, Turkey) after removing the core and handle portions grinders. The obtained purees were kneaded with yoghurt, dried mint, yeast, water and $450 \mathrm{~g}$ flour in the amounts given in Table 1 for 3 minutes at $50 \mathrm{rpm}$ (Kenwood, UK). The resulting tarhana dough was allowed to ferment at $30^{\circ} \mathrm{C}$. During fermentation, the samples were stored in sealed plastic boxes and mixed 3 times a day. $135 \mathrm{~g}$ flour was added on the second day of fermentation. This is due to provide the rapid development of fermentation by keeping the water content high. Otherwise, mold growth is observed during fermentation in lentil tarhana with high dietary fiber content. Fermentation was continued until the total acidity of the samples reached 15 . The remaining flour and salt were added to the fermented samples and mixed to obtain hard dough. The obtained dough was shredded to 5-6 g on trays and dried under room conditions (traditional) until the moisture content decreased to $10 \%$. Tarhana samples which drying process completed were grinded in the blander (Waring, USA) until their particles' size became less than 400 microns and kept in glass jars until they were analyzed in the dark and at room temperature.

\subsection{Preparation of tarhana soup for sensory analysis}

In the preparation of tarhana soups from milled tarhanas, the prescription of Isik \& Yapar (2014) containing 4.5\% tarhana powder, $88.3 \%$ water, $4.5 \%$ corn oil, $2.2 \%$ tomato paste and $0.5 \%$ salt were used. Before proceeding with cooking stage of the soups, $25 \%$ of the water to be used was added to tarhana powder and mixed until tarhana disolved. In soup production, firstly corn extract was placed in the pot and heated to $150{ }^{\circ} \mathrm{C}$ and roasted for 2 minutes by adding tomato paste. The tarhana, which was then mix with water, was added to the pot with the remaining water and salt. After the mixture reached boiling point, it was allowed to boil for 15 minutes. Prepared tarhana soups were presented to the panelists at constant temperature $\left(70^{\circ} \mathrm{C}\right)$ and simultaneously.

\subsection{Chemical analysis of tarhanas}

Tarhana's total dry matter, crude ash, crude protein and crude fat contents were determined according to the methods of AOAC (Association of Official Analytical Chemists, 1990). Acidity degree values were determined according to TS Tarhana Standard (Anonymous, 1981). The $\mathrm{pH}$ measurement was performed with a digital $\mathrm{pH}$ meter (Hanna Instruments HI 8314). After $5 \mathrm{~g}$ sample was mixed with $100 \mathrm{ml}$ of pure water and homogenizer for 3 minutes and filtered through ordinary filter paper, $\mathrm{pH}$ values were determined by reading the probe by immersion in this filtrate (İbanoğlu et al., 1999). The dietary fiber content of tarhanas was determined according to the total dietary fiber measurement kit (Megazyme K-TDFR, Wicklow, Ireland) and the methods of Mes-Tris AOAC 991.43 (Association of Official Analytical Chemists, 1995) and AACC 32-07 (American Association of Cereal Chemists, 1995). First, the weighed sample was gelatinized at $95-100{ }^{\circ} \mathrm{C}$ with heat-resistant $\alpha$-amylase to hydrolyze the digestible starch. Subsequently, enzymatic digestion was performed with protease and amyloglycosidase enzymes at $60{ }^{\circ} \mathrm{C}$ to remove the digestible proteins. The mixture was filtered with vacuum and the supernatant was washed firstly with distilled water and followed by ethanol and acetone. This

Table 1. Formulations of tarhana production.

\begin{tabular}{ccccccccccccc}
\hline $\begin{array}{c}\text { Tarhana } \\
\text { Samples }\end{array}$ & $\begin{array}{c}\text { WF } \\
(\mathrm{g})\end{array}$ & RLF $(\mathrm{g})$ & GLF $(\mathrm{g})$ & $\begin{array}{c}\text { YLF } \\
(\mathrm{g})\end{array}$ & $\begin{array}{c}\text { Yoghurt } \\
(\mathrm{g})\end{array}$ & $\begin{array}{c}\text { Tomato } \\
\text { puree } \\
(\mathrm{g})\end{array}$ & $\begin{array}{c}\text { Red } \\
\text { pepper } \\
\text { puree }(\mathrm{g})\end{array}$ & $\begin{array}{c}\text { Onion } \\
\text { puree } \\
(\mathrm{g})\end{array}$ & $\begin{array}{c}\text { Dry Mint } \\
(\mathrm{g})\end{array}$ & $\begin{array}{c}\text { Yeast } \\
(\mathrm{g})\end{array}$ & $\begin{array}{c}\text { Salt }(\mathrm{g}) \\
(\mathrm{mL})\end{array}$ \\
\hline CT & 1000 & - & - & - & 304 & 135 & 68 & 24 & 14 & 7 & 11 & - \\
RLT & - & 1000 & - & - & 304 & 135 & 68 & 24 & 14 & 7 & 11 & 472 \\
GLT & - & - & 1000 & - & 304 & 135 & 68 & 24 & 14 & 7 & 11 & 607 \\
YLT & - & - & - & 1000 & 304 & 135 & 68 & 24 & 14 & 7 & 11 & 472 \\
\hline
\end{tabular}

${ }^{\star}$ CT: Control Tarhana, RLT: Red lentil tarhana, GLT: Green lentil tarhana, YLT: Yellow lentil tarhana, WF: Wheat flour, RLF: Red lentil flour, GLF: Green lentil flour and YLF: yellow lentil flour. 
residual part, which washing process has been completed, contains insoluble dietary fiber, insoluble salt and nondigestible proteins. The collected filtrate was added ethanol and allowed to stand at room conditions for 1 hour to precipitate the soluble fraction of dietary fiber. Then the precipitate was filtered off and washed with ethanol and acetone. This precipitate also contains soluble fraction of dietary fiber, minerals and nondigestible proteins. Afterwards, residual protein, ash and blank quantities were detected and total dietary fiber contents by being subjected to protein and ash analysis were determined by verifying in order to detect the remaining proteins and salt in their structures.

\subsection{Mineral substance analysis}

$0.5 \mathrm{~g}$ of tarhana samples were taken from tarhana samples which dried at $70{ }^{\circ} \mathrm{C}$ and grinded in blander, $6 \mathrm{ml}$ of $\mathrm{HNO}_{3}$ and $2 \mathrm{ml}$ of $\mathrm{H}_{2} \mathrm{O}_{2}$ were added, the mixture was left to stand for 30 minutes and in microwave method of wet decomposition was fulfilled. Samples burnt in microwave were filtered through filter paper and $\mathrm{P}, \mathrm{K}, \mathrm{Ca}, \mathrm{Mg}, \mathrm{Fe}, \mathrm{Cu}, \mathrm{Mn}$ and $\mathrm{Zn}$ contents were determined in inductively coupled plasma optical emission spectrometry (ICP-OES, Perkin Elmer, Optima 2100 DV, Massachusetts, US).

\subsection{Total phenolic content and antioxidant activity analysis}

For total phenolic and antioxidant activity analyzes, extracts were first prepared from tarhana samples: After mixed with methanol/distilled water (DW) $(70 / 30 \%, v / v)$ in a ratio of $1: 10(\mathrm{w} / \mathrm{v})$ and the mixture was placed in an ultrasonic water bath (Apple E $60 \mathrm{H}$, Germany) for 10 minutes and on a mechanical shaker (WiseShake SHO-1D, Germany) stirred at room temperature for 15 minutes, the milled tarhana samples was centrifuged (Hettich, Universal 30 RF, Germany) for 20 minutes at $26.000 \times \mathrm{g}$ at $4{ }^{\circ} \mathrm{C}$. The upper supernatant was collected into amber flasks with glass pasteur pipettes. Extraction to the precipitate at the bottom of the centrifuge tubes was repeated once more. The collected supernatants were stored at $24^{\circ} \mathrm{C}$ until analysis.

The amount of the total phenolic substance was found according to the Folin-Ciocalteu (FC) method (Singleton et al., 1999). The calibration curve was generated using the gallic acid solutions in the concentration range of 5-100 $\mathrm{mg} / \mathrm{L}$. In the analysis of the samples, $1 \mathrm{~mL}$ of sample extract was mixed with $5 \mathrm{~mL}$ of 1:10 (v/v) FC/DW solution and $4 \mathrm{ml}$ of $75 \mathrm{~g} / \mathrm{L} \mathrm{Na}_{2} \mathrm{CO}_{3}$. After kept the mixtures 2 hours at room temperature and darkness, the absorbance values were read on spectrophotometer (PG-80 UV-Vis Spectrometer, PG Instruments, England) at $760 \mathrm{~nm}$. For the results, the total phenolic content in each gram of dry sample was calculated as $\mathrm{mg}$ gallic acid equivalent (GAE).

Determination of antioxidant activity was performed using 2.2-diphenyl-1-picrylhydrazyl (DPPH) method (Thaipong et al., 2006). The calibration curve was generated by using trolox solutions in the range of 10-50 $\mu \mathrm{M}$. The stock solution was prepared by completing $24 \mathrm{mg}$ of DPPH with $100 \mathrm{ml}$ of methanol and maintaining the solution at $20^{\circ} \mathrm{C}$ until being used. The working solution was obtained by mixing $10 \mathrm{ml}$ of the stock solution with $45 \mathrm{ml}$ of methanol. The absorbance of this solution in the spectrophometer (PG-80 UV-Vis Spectrometer, PG Instruments,
England) at $515 \mathrm{~nm}$ wavelength was provided to be $1.1 \pm 0.02$. In analysis; $150 \mu \mathrm{L}$ of tarhana extract was mixed with $2850 \mu \mathrm{L}$ DPPH solution and incubated for 1 hour in the dark at room temperature and their absorbance at $515 \mathrm{~nm}$ was measured. Results were calculated as $\mu \mathrm{mol}$ Trolox equivalent (TE)/g sample on dry matter basis.

\subsection{Color analysis}

Color values of tarhanas were calculated with $\mathrm{L}$ [0-100 $=$ darkness-lightness $], \mathrm{a}[\mathrm{a}+=\mathrm{red}, \mathrm{a}-=$ green $]$ and $\mathrm{b}$ $[\mathrm{b}+=$ yellow, $\mathrm{b}-=$ blue], Hunter-Lab Mini Scan XE color meter device (Reston, VA, USA) (Anonymous, 1995).

\subsection{Viscosity measurement}

Tarhana/DW mixture of $10 \%(\mathrm{w} / \mathrm{v})$ was prepared to determine the viscosity values. After this mixture was stirred in a mechanical shaker for 10 minutes, it was heated in a water bath and boiled for 10 minutes. Tarhana/DW mixtures consistency coefficient $(K)$ and flow behaviour index $(n)$ values were measured by Brookfield programmable DV-II+(Middleboro, Massachusetts, USA) viscometer. From the sample prepared for analysis, it was transferred to the sample vessel (Brookfield Accessories, SC4-13R) connected to the circulating water bath and at $70^{\circ} \mathrm{C}$ with the head SC4-21 (Brookfield Accessories) at 19 different speeds $(1,1.8,2,7.5,10,15,20,30,40,50,60,70$, $80,100,120,140,150,180$ and $200 \mathrm{rpm}) K$ and $n$ values were determined. The power-law model " $\delta=K(\gamma) n$ " was used to determine the flow behavior characteristics of tarhana/DW mixtures.

\subsection{Microbiological analysis}

Total mesophile aerob bacteria (TMAB) count, yeast-mold (YM) count and total lactic acid bacteria (LAB) count were performed for microbiological analysis in tarhanas. Planting was done with the methods of spreading from dilutions, which prepared in appropriate ways. Colonies that develop as a result of necessary incubations were given in type of $\log \mathrm{cfu} / \mathrm{g}$. For TMAB count, in Plate Count Agar medium (PCA; Merck 1.05463) planting was done. After planting, it was incubated at $30^{\circ} \mathrm{C}$ for 48 hours. For YM count, in Dichloran Rose-Bengal Chloramphenicol Agar medium (DRBC; Merck 1.00466) planting was done. Planting plates were incubated at $28-30{ }^{\circ} \mathrm{C}$ for 5 days. Cultures of LAB were carried out on De Man Rogosa Sharpe Agar (MRS; Merck 1.10660). Colonies formed after $48 \mathrm{~h}$ incubation at $30^{\circ} \mathrm{C}$ in petri dishes were counted. After MRS Agar was sterilized, by adding $0.01 \%(\mathrm{v} / \mathrm{v})$ of $10 \mathrm{mg} / \mathrm{mL}$ cycloheximide solution on the medium, which was prepared and filtered beforehand, selective property was redounded to the medium for LAB count (Anonymous, 2005).

\subsection{Scanning electron microscopy}

The surface morphology of tarhana powders was investigated by scanning electron microscopy (SEM). The tarhana samples were bonded onto a carbon plate for conductivity prior to analysis and then coated with a mixture of Gold/Palladium 
(80:20/w:w) at room temperature (Quorum, Q150R ES, UK). The samples were imaged with SEM (ZEISS, SUPRA, 40VP, GERMANY) at $5 \mathrm{kV}$. Images of the samples were obtained with 250, 500, 1000 and 4000 times magnification.

\subsection{Sensory analysis}

In the sensory analysis test, a panelist group of 56 (30 Male, 26 Female) people aged between 18 and 50 years was used. Students, administrative staff and academic staff of Aydin Adnan Menderes University Çine Vocational School took part in the sensory evaluation. The panelists evaluated the soups in the range of 1 to 7 points on the hedonic scale in terms of taste, smell, flavor, consistency and general acceptance. The prepared tarhana soups were presented to the panelists at constant temperature $\left(70^{\circ} \mathrm{C}\right)$ and simultaneously. The soups were coded in randomly selected 3-digit numbers before presentation. After each sample group was tested, it was ensured that unsalted bread and water were used to neutralizee the inside of the mouth for the next test (Isik \& Yapar, 2014).

\subsection{Statistical analysis}

Data were analyzed using "Minitab 16 Statistical Program". ANOVA (One-way analysis of variance) and Tukey (Multiple comparison test) tests were used to detect significant differences $(\alpha=0.05)$.

\section{Results and discussion}

Chemical compositions consisted of total dry matter, crude ash, crude protein, crude fat, titratable acidity, $\mathrm{pH}$ degree, soluble, unsoluble and total dietary fibre of tarhanas is given at Table 2. As seen at that table, there is no statistical difference between samples according to total dry matter. Green lentil tarhana is contained crude ash, soluble, insoluble and total dietary fibre more than other tarhanas $(\mathrm{p}<0.05)$. When tarhanas compared in terms of crude protein and crude fat, it is found that red lentil tarhana has them more than others. The yellow lentil tarhana is determined with having the highest acidity and the lowest $\mathrm{pH}$ degree. It is determined that tarhanas which are obtained from wheat flour instead of lentil flour have significantly dietary fibre, crude protein and crude ash. It is found that generally chemical analysis results of lentil tarhanas are higher than control tarhana. Five different commercial tarhana samples were examined in a study by O'Callaghan et al. (2019) and it was reported crude protein, crude fat and total dietary fibre ranged between 8.7-11.7\%, $2.7-5.4 \%$ and $3.0-4.2 \%$ respectively. When compared to commercial tarhana and control tarhana, the control tarhana was found to be very rich in protein, while it was identified to contain less fat and dietary fiber. When compared to the control tarhana in Isik \& Yapar (2017)'s study and the control tarhana we produced; one hand, our tarhana was found to be richer in terms of \% crude protein, soluble, insoluble and total dietary fiber on the other hand it was found to be poorer in terms of \% crude fat and $\%$ crude ash.

Mineral matter composition was seen at Table 3. No significant $(p>0.05)$ difference was found between the tarhanas in terms of $\mathrm{P}, \mathrm{Mg}, \mathrm{Fe}$ and $\mathrm{Mn}$. Red lentil tarhana had the highest value in terms of $\mathrm{Cu}$ and $\mathrm{Zn}$, while control tarhana had the highest value in terms of $\mathrm{Ca}$. Tarhana with the highest $\mathrm{K}$ value was yellow lentil tarhana. Other elements except $\mathrm{Ca}$ and $\mathrm{Mn}$ were higher than control tarhana. It was determined that the $\mathrm{K}, \mathrm{Cu}$ and $\mathrm{Zn}$ values of tarhanas which were obtained from lentil flour instead of wheat flour were significantly increased. When compared to the control tarhana in Isik \& Yapar (2017)'s study and our tarhana; $\mathrm{P}, \mathrm{K}, \mathrm{Ca}, \mathrm{Mg}$ and $\mathrm{Mn}$ elements were higher in our control tarhana; $\mathrm{Fe}, \mathrm{Cu}$ and $\mathrm{Zn}$ were less. Ozbek \& Ozcan (2017) examined 13 different tarhana samples, the amount of $\mathrm{K}, \mathrm{Ca}, \mathrm{Mg}, \mathrm{Fe}$ and $\mathrm{Mn}$ by microwave - induced plasma - atomic absorption spectrometry (MIP - AES) were determined. As a result, it was reported that 0.19-0.40 for K (\%), 0.06-0.16 for Ca (\%), 0.04-0.14 for Mg (\%), and 16-61for $\mathrm{Fe}(\mathrm{ppm})$ and $\mathrm{Mn}(\mathrm{ppm})$ were in the range of 19-43. In another study (Daglioglu, 2000), it was determined they were respectively in the range of $\mathrm{K}(\%) 0.06-0.18, \mathrm{Ca}(\%)$ 0.05-0.19, Mg (\%) 0.03-0.13, Fe (ppm) 21-59, Zn (ppm) 8-32. When compared to the studies, $K$ and Ca values were found to be higher in our tarhanas and $\mathrm{Mn}$ values were lower. $\mathrm{Mg}$, Fe and $\mathrm{Zn}$ were in the stated ranges in the studies.

When the phenolic matter content and antioxidant activities of legumes were examined, it was seen that flavonoids were dominant and the grains exhibited antioxidant activity due to phenolic component contents (Amarowicz \& Pegg, 2008). It was determined that the highest antioxidant activity value and total phenolic content among the tarhanas were found in the green lentil tarhana. Antioxidant activity value and total phenolic matter content of lentil tarhanas were very high compared to control tarhana. The antioxidant activity value and total

Table 2. Chemical Compositions of Tarhanas*.

\begin{tabular}{lccrr}
\hline \multicolumn{1}{c}{ Samples $^{* *}$} & CT & RLT & GLT & YLT \\
\hline Total dry matter (\%) & $93.95 \pm 0,19 \mathrm{a}$ & $93.75 \pm 0.08 \mathrm{a}$ & $93.94 \pm 0.05 \mathrm{a}$ & $93.88 \pm 0.01 \mathrm{a}$ \\
Crude ash (\%) & $2.822 \pm 0.016 \mathrm{c}$ & $3.254 \pm 0.016 \mathrm{~b}$ & $3.683 \pm 0.099 \mathrm{a}$ & $3.090 \pm 0.084 \mathrm{bc}$ \\
Crude protein (\%) & $17.01 \pm 0.13 \mathrm{c}$ & $29.75 \pm 0.12 \mathrm{a}$ & $26.03 \pm 0.24 \mathrm{~b}$ & $25.67 \pm 0.14 \mathrm{~b}$ \\
Crude oil (\%) & $2.17 \pm 0.01 \mathrm{c}$ & $3.07 \pm 0.03 \mathrm{a}$ & $2.78 \pm 0.06 \mathrm{~b}$ & $2.98 \pm 0.03 \mathrm{a}$ \\
Titratable acidity & $30.25 \pm 0.35 \mathrm{c}$ & $35.25 \pm 0.35 \mathrm{~b}$ & $36.25 \pm 0.35 \mathrm{~b}$ & $42.75 \pm 0.35 \mathrm{a}$ \\
pH & $4.64 \pm 0.01 \mathrm{a}$ & $4.68 \pm 0.00 \mathrm{a}$ & $4.64 \pm 0.02 \mathrm{a}$ & $4.37 \pm 0.00 \mathrm{~b}$ \\
Soluble dietary fiber (\%) & $1.15 \pm 0.04 \mathrm{c}$ & $1.32 \pm 0.01 \mathrm{~b}$ & $1.51 \pm 0.02 \mathrm{a}$ & $1.39 \pm 0.00 \mathrm{~b}$ \\
Insoluble dietary fiber (\%) & $1.64 \pm 0.01 \mathrm{~d}$ & $11.01 \pm 0.04 \mathrm{c}$ & $17.20 \pm 0.01 \mathrm{a}$ & $13.99 \pm 0.03 \mathrm{~b}$ \\
Total dietary fiber (\%) & $2.79 \pm 0.03 \mathrm{~d}$ & $12.33 \pm 0.04 \mathrm{c}$ & $18.71 \pm 0.01 \mathrm{a}$ & $15.38 \pm 0.03 \mathrm{~b}$ \\
\hline
\end{tabular}

${ }^{\star}$ It was calculated according to dry matter; CT: Control Tarhana, RLT: Red lentil tarhana, GLT: Green lentil tarhana, YLT: Yellow lentil tarhana, pH:Acidity Degree. ${ }^{\star}$ Different letters within the same column, it was shown that there were statistically significant differences between samples $(\alpha=0.05)$. 
phenolic matter content of tarhanas was seen at Table 4 . When compared to the control tarhana in Isik \& Yapar (2017)'s study and our tarhana; it was seen that the results of both analyzes overlapped and were very close. In Cagindi et al. (2016)'s study, total phenolic content were identified by obtaining 27 different domestic and commercial tarhanas in Turkey. The results were given in the range of 5.50-426.70 mgGAE/100 g. While all of our tarhana examples were within these limits, compared to the results (64.4-179.7 mgGAE/100 g) of O'Callaghan et al. (2019)'s study, it was seen to be higher.

Lentils, because of containing high flavonoids (Oomah et al., 2011) grain colors also change according to the variety and amount of flavonoids. The color values of the tarhans were given in Table 4. From the highest to the lowest, the $\mathrm{L}$ value was the control tarhana, yellow lentil tarhana, green lentil tarhana and red lentil tarhana, respectively. The darkest tarhana was the red lentil tarhana and the lightest one was the control tarhana. Since + a represents red, -a represents green, the highest a value was obtained in red lentil tarhana and the lowest a value was found in green lentil tarhana. $+\mathrm{b}$ represents yellow and $-\mathrm{b}$ represents blue. Accordingly, the yellowness values were measured from the highest to the lowest in the control, red, yellow and green lentil tarhans, respectively. In the study of Cagindi et al. (2016) for the commercial and local tarhana samples collected from the market, $\mathrm{L}$ values $54.61-88.57$, a value of $0.14-28.10$ and $\mathrm{b}$ in the range of 1.43-52.88 were determined as a wide range. Again Köse \& Çağındı (2002) and Gül (2010) reported that L, $\mathrm{a}$ and $\mathrm{b}$ values were in the range of 52.71-63.03, 14.41-18.72, 33.41-44.14 and 44.03-59.22, 19.4-20.7, 29.71-35.29 respectively in their study. When these three studies were compared, it was understood that the $\mathrm{L}$, $\mathrm{a}$ and $\mathrm{b}$ values of our tarhanas were within the specified ranges.

Tarhana samples were found to be pseudoplastic type fluids at $70^{\circ} \mathrm{C}$ (Table 5). When coefficients of consistence were compared, this value of control tarhana was higher than lentil tarhana $(\mathrm{p}<0.05)$. According to flow behavior index, control and red lentil tarhanas were similar, whereas green and yellow lentil tarhanas were similar. Erbaş et al. (2005) and Hayta et al. (2002) reported that the tarhanas they produced were pseudoplastic type fluids. The rheological properties of tarhanas with wheat bran addition were examined by Çelik et al. (2010)'s study. They reported that tarhanas added to bran at $70{ }^{\circ} \mathrm{C}$ had a decrease in both $\mathrm{K}$ and $\mathrm{n}$ values compared to control tarhana.

When looking at Table 5, the microbiological counting results of tarhanas were seen. There was no difference $(\mathrm{p}>0.05)$ between lentil tarhanas when the LAB countings were taken into consideration. However, the number of LABs of lentil tarhanas was higher than that of control tarhanas. The reason of this;

Table 3. Mineral matter composition of Tarhanas*.

\begin{tabular}{|c|c|c|c|c|}
\hline Samples ${ }^{* *}$ & $\mathrm{P}(\%)$ & K (\%) & $\mathrm{Ca}(\%)$ & $\mathrm{Mg}(\%)$ \\
\hline $\mathrm{CT}$ & $0.46 \pm 0.09 a$ & $0.50 \pm 0.02 b$ & $0.31 \pm 0.02 \mathrm{a}$ & $0.11 \pm 0.01 \mathrm{a}$ \\
\hline RLT & $0.55 \pm 0.04 a$ & $1.12 \pm 0.01 \mathrm{a}$ & $0.25 \pm 0.01 b$ & $0.12 \pm 0.01 a$ \\
\hline GLT & $0.56 \pm 0.04 a$ & $1.08 \pm 0.04 a$ & $0.30 \pm 0.01 \mathrm{ab}$ & $0.13 \pm 0.01 a$ \\
\hline YLT & $0.63 \pm 0.08 \mathrm{a}$ & $1.18 \pm 0.13 a$ & $0.24 \pm 0.00 \mathrm{~b}$ & $0.11 \pm 0.01 \mathrm{a}$ \\
\hline Samples ${ }^{\star *}$ & $\mathrm{Fe}(\mathrm{ppm})$ & $\mathrm{Cu}(\mathrm{ppm})$ & $\mathrm{Mn}(\mathrm{ppm})$ & $\mathrm{Zn}(\mathrm{ppm})$ \\
\hline $\mathrm{CT}$ & $26.29 \pm 0.47 a$ & $1.65 \pm 0.12 b$ & $9.12 \pm 0.20 \mathrm{a}$ & $9.62 \pm 0.84 c$ \\
\hline RLT & $36.56 \pm 0.20 \mathrm{a}$ & $4.55 \pm 0.29 a$ & $7.16 \pm 0.33 a$ & $19.60 \pm 0.70 a$ \\
\hline GLT & $43.29 \pm 0.45 a$ & $3.72 \pm 0.10 \mathrm{a}$ & $6.02 \pm 0.01 \mathrm{a}$ & $15.11 \pm 0.76 b$ \\
\hline YLT & $32.69 \pm 0.99 a$ & $2.36 \pm 0.31 b$ & $5.00 \pm 0.07 a$ & $14.69 \pm 0.58 b$ \\
\hline
\end{tabular}

${ }^{*}$ It was calculated according to dry matter; CT: Control Tarhana, RLT: Red lentil tarhana, GLT: Green lentil tarhana, YLT: Yellow lentil tarhana. ${ }^{* *}$ Different letters within the same column, it was shown that there were statistically significant differences between samples $(\alpha=0.05)$.

Table 4. Antioxidant Activity ${ }^{\star}$, Total Phenolic Matter Content ${ }^{\star}$ and Color Values of Tarhanas.

\begin{tabular}{cccrrr}
\hline Samples* $^{*}$ & $\begin{array}{c}\text { Antioxidant activity } \\
(\mu \mathrm{mol} \mathrm{TE} / 100 \mathrm{~g})\end{array}$ & $\begin{array}{c}\text { Total phenolic content } \\
(\mathrm{mgGAE} / 100 \mathrm{~g})\end{array}$ & $L$ & $a$ & $b$ \\
\hline CT & $10.93 \pm 0.14 \mathrm{~d}$ & $201.94 \pm 0.12 \mathrm{~d}$ & $60.53 \pm 0.50 \mathrm{a}$ & $8.71 \pm 0.04 \mathrm{~b}$ & $18.22 \pm 0.11 \mathrm{a}$ \\
RLT & $19.07 \pm 0.50 \mathrm{c}$ & $214.51 \pm 0.26 \mathrm{c}$ & $50.48 \pm 0.55 \mathrm{~b}$ & $14.93 \pm 0.02 \mathrm{a}$ & $17.93 \pm 0.19 \mathrm{a}$ \\
GLT & $39.87 \pm 0.48 \mathrm{a}$ & $389.18 \pm 0.32 \mathrm{a}$ & $51.81 \pm 0.02 \mathrm{~b}$ & $3.56 \pm 0.13 \mathrm{~d}$ & $15.14 \pm 0.01 \mathrm{~b}$ \\
YLT & $25.41 \pm 0.26 \mathrm{~b}$ & $357.05 \pm 0.18 \mathrm{~b}$ & $59.51 \pm 0.38 \mathrm{a}$ & $5.14 \pm 0.33 \mathrm{c}$ & $17.77 \pm 0.04 \mathrm{a}$ \\
\hline
\end{tabular}

*It was calculated according to dry matter; CT: Control Tarhana, RLT: Red lentil tarhana, GLT: Green lentil tarhana, YLT: Yellow lentil tarhana, L [0-100 = darkness-lightness], a $[a+=$ red, $a-=$ green $]$ and $b[b+=$ yellow, $b-=$ blue $] .{ }^{*}$ Different letters within the same column, it was shown that there were statistically significant differences between samples $(\alpha=0.05)$.

Table 5. Microbiological countings of tarhanas (log cfu/g) and tarhanas’ consistency coefficients (Pa.sn) and flow behavior index values at $70{ }^{\circ} \mathrm{C}^{\star}$.

\begin{tabular}{cccccc}
\hline Samples & LAB & YM & TMAB & $K$ & $n$ \\
\hline CT & $7.17 \pm 0.03 \mathrm{~b}$ & $4.72 \pm 0.03 \mathrm{c}$ & $7.05 \pm 0.07 \mathrm{a}$ & $5.05 \pm 0.36 \mathrm{a}$ & $0.36 \pm 0.0 \mathrm{a}$ \\
RLT & $8.32 \pm 0.03 \mathrm{a}$ & $5.53 \pm 0.03 \mathrm{a}$ & $6.81 \pm 0.04 \mathrm{a}$ & $3.30 \pm 0.55 \mathrm{~b}$ & $0.37 \pm 0.0 \mathrm{a}$ \\
GLT & $8.24 \pm 0.02 \mathrm{a}$ & $5.09 \pm 0.12 \mathrm{~b}$ & $7.24 \pm 0.05 \mathrm{a}$ & $3.20 \pm 0.17 \mathrm{~b}$ & $0.31 \pm 0.0 \mathrm{~b}$ \\
YLT & $8.30 \pm 0.01 \mathrm{a}$ & $5.33 \pm 0.04 \mathrm{ab}$ & $6.15 \pm 0.21 \mathrm{~b}$ & $2.40 \pm 0.14 \mathrm{~b}$ & $0.32 \pm 0.0 \mathrm{~b}$ \\
\hline
\end{tabular}

${ }^{*}$ Different letters within the same column, it was shown that there were statistically significant differences between samples ( $\left.\alpha=0.05\right)$. CT: Control Tarhana, RLT: Red lentil tarhana, GLT: Green lentil tarhana, YLT: Yellow lentil tarhana, LAB: total lactic acid bacteria count, TMAB: Total mesophile aerob bacteria count, YM: yeast-mold count , K : consistency coefficient and n: flow behaviour index. 
while preparing tarhana dough, adding additional water to the lentil formulations. When the YM countings were examined, the number of lentil tarhanas was higher than the control tarhana. In terms of TMAB counting, it was seen that yellow lentil tarhana had less $(\mathrm{p}<0.05)$ amount of TMAB than other tarhanas. In the study of Daglioglu at al. (2002), the effect of the drying method on the number of microorganisms in tarhana were examined and the results of control samples obtained by convectional drying (LAB:4.85, YM:3.70 and TMAB:5.48 log cfu/g) were found to be lower than the number of microorganisms of our tarhanas.

At Figure 1, the micrographs of the tarhana samples were obtained at 4 different magnification ratios in scanning electron microscopy was seen. According to micrographs, a wide particle distribution was observed. While the control tarhana and red lentil tarhana giving a similar image by consisting of smaller particles, it was shown that the green and yellow lentil tarhanas were consisted of larger particles. Small $(100 \mu \mathrm{m})$ particles were irregularly viewed in all tarhana varieties. Salameh et al. (2016) also reported similar irregularities in their research on kishk. In addition, large clustering images were obtained in green and yellow lentil tarhanas. At the highest magnification rate (x 4000), it was viewed some of the particles were covered with a thin layer. It was reported that they had fat layers in different studies (Salameh et al., 2016; Do et al., 2011), only a certain portion of the particles, not all, were covered by a thin film. This is due to the fact that tarhanas do not have high fat content.

Sensory analysis results were given in Table 6. In all tarhana varieties and all parameters, panelists gave scores above the mid-score of 3.5 on the hedonic scale. When all tarhana soups were taken into consideration, it was determined that there was no difference ( $p$ > 0.05) in terms of color, smell, flavor, consistency and general taste. When the general appreciation was observed, it was found that the yellow lentil tarhana had the highest average score $(4.60 \pm 0.60)$. This was followed by control tarhana $(4.46 \pm 0.60)$, red lentil tarhana $(4.41 \pm 0.42)$ and green lentil tarhana ( $4.25 \pm 0.15)$. In the study of Bilgiçli (2009), wheat flour was replaced by buckwheat flour at the rate of $20 \%, 40 \%$, $60 \%, 80 \%$ and $100 \%$ and tarhanas were obtained. He stated that buckwheat flour can be used in tarhana production at the rate of maximum $40 \%$ when sensory properties were considered. Levent (2019), on the other hand, produced gluten-free tarhana using the hulls and flour of some legumes and tarhana soups without compromising the acceptability of faba beans, common beans and chickpea hulls up to $8 \%$, the flour up to $20 \%$ can be used by replacing. In addition, Demir (2014) produced gluten-free tarhanas at the rate of $40 \%, 50 \%$ and $60 \%$ by substituting quinoa and stated that $50 \%$ substituted tarhana received higher total appreciation than $60 \%$ substituted tarhana. Chestnut flour was used in the production of gluten-free tarhana which was made by Koca et al. (2017) and they received statistically lower scores than the control tarhana in terms of total acceptability (general appreciation). It is understood that the tarhana obtained by using lentil flour in the production of gluten-free tarhana has similar score with the control tarhana and can be preferred more than the tarhana obtained from buckwheat, faba bean, common bean, chickpea and quinoa flour.

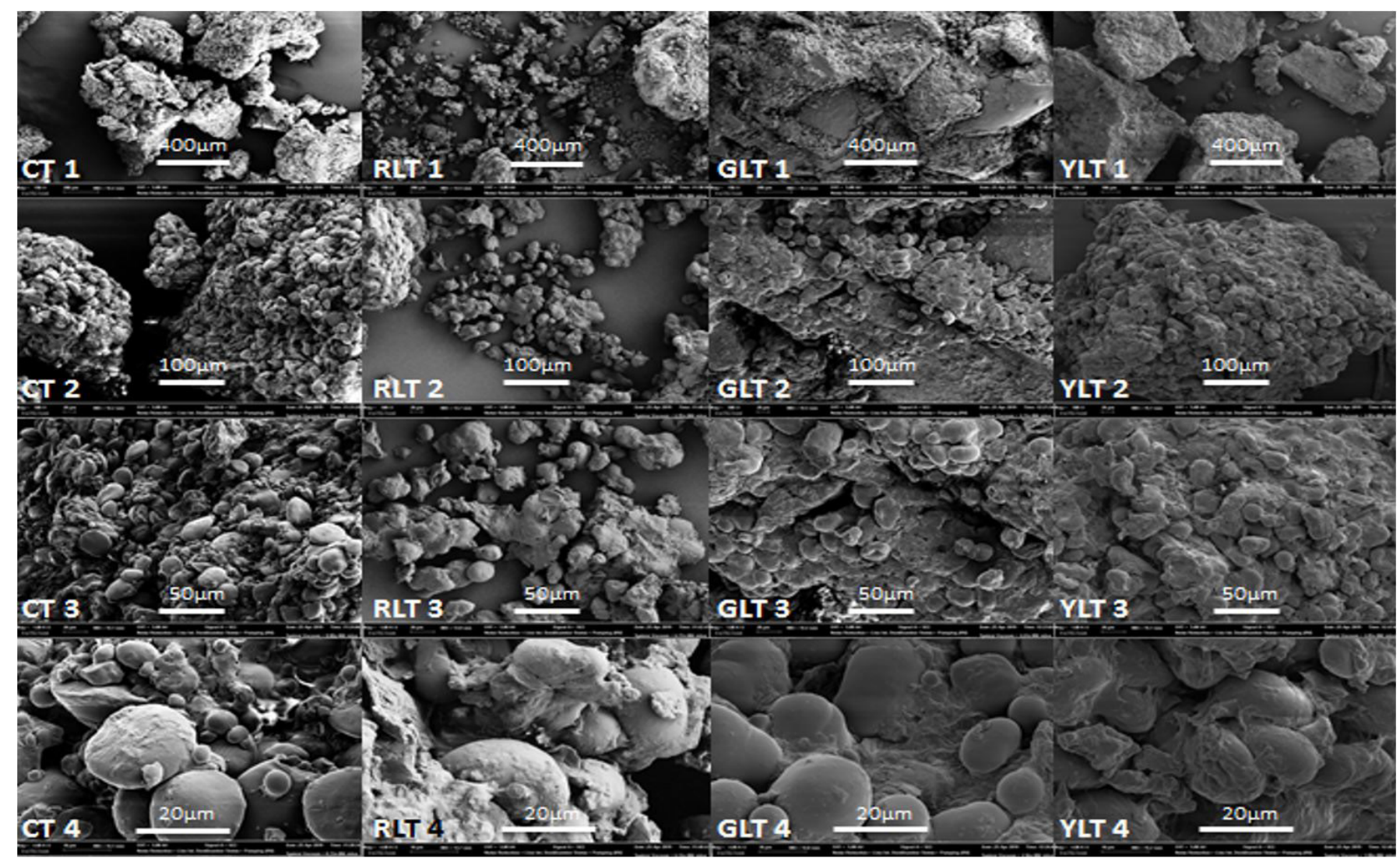

Figure 1. SEM micrographs of Tarhanas ${ }^{*}{ }^{*}$ Magnifications; 1: x 150, 2: x 500, 3: x 1000 ve 4: x 4000. 
Table 6. Sensory Analysis Results of Tarhanas.

\begin{tabular}{cccccc}
\hline Samples $^{\star}$ & Color & Smell & Flavor & Consistency & Overall acceptance \\
\hline CT & $4.87 \pm 0.37 \mathrm{a}$ & $4.33 \pm 0.42 \mathrm{a}$ & $4.41 \pm 0.32 \mathrm{a}$ & $4.39 \pm 0.35 \mathrm{a}$ & $4.46 \pm 0.60 \mathrm{a}$ \\
RLT & $4.50 \pm 0.20 \mathrm{a}$ & $4.50 \pm 0.30 \mathrm{a}$ & $4.25 \pm 0.75 \mathrm{a}$ & $4.50 \pm 0.50 \mathrm{a}$ & $4.41 \pm 0.42 \mathrm{a}$ \\
GLT & $4.16 \pm 0.42 \mathrm{a}$ & $4.25 \pm 0.05 \mathrm{a}$ & $4.39 \pm 0.05 \mathrm{a}$ & $4.23 \pm 0.37 \mathrm{a}$ & $4.25 \pm 0.15 \mathrm{a}$ \\
YLT & $4.53 \pm 0.45 \mathrm{a}$ & $4.32 \pm 0.35 \mathrm{a}$ & $4.41 \pm 0.68 \mathrm{a}$ & $4.57 \pm 0.30 \mathrm{a}$ & $4.60 \pm 0.60 \mathrm{a}$ \\
\hline
\end{tabular}

${ }^{\star}$ Different letters within the same column, it was shown that there were statistically significant differences between samples ( $\left.\alpha=0.05\right)$. CT: Control Tarhana, RLT: Red lentil tarhana, GLT: Green lentil tarhana, YLT: Yellow lentil tarhana.

\section{Conclusion}

In this study, it was determined that tarhanas which were produced by using red, green and yellow lentil flours had very rich content in terms of crude fat, crude protein, crude ash, soluble, insoluble and total dietary fiber. In addition, it was also determined that the elements other than $\mathrm{Ca}$ and $\mathrm{Mn}$ were higher than the control tarhanas when the mineral content was examined. Total phenolic content and antioxidant activity values of lentil tarhana were found to be much better than the control tarhana. When lentil tarhanas were compared, green lentil tarhanas were found to be the richest tarhana according to soluble, insoluble and total dietary fiber, crude ash, total phenolic content and antioxidant activity values. Lentil tarhanas are also higher in terms of LAB number than control tarhana. Considering all these, a significant increase in tarhana's nutritional value occured with using the lentil tarhanas instead of wheat flour in the production of tarhana. Lentils have high protein content and have superior nutritional value due to their high digestibility and rich amino acids compared to cereal proteins. With its high dietary fiber content, it had supportive digestive system, its fibers have prebiotic properties and functions such as lowering blood sugar, protecting against cardiovascular diseases, cancer and regulating the digestive system. It is also an important product for intestinal health with its high LAB content. In sensory analyzes; red, green and yellow lentil tarhanas scored similar to control tarhana and even the highest score among all tarhana samples was obtained by yellow lentil tarhanas, so it shows that lentil tarhanas do not have any strange or disturbing taste compared to traditional tarhana. According to this, it is understood that consumers can prefer these tarhanas. With this product, both lentil consumption can be increased and a healthier tarhana soup can be obtained.

\section{Acknowledgements}

This study was funded by Pamukkale University, Unit of Scientific Research Projects (BAP), Turkey (Project No: 2018FEBE025).

\section{References}

Aguilera, Y., Estrella, I., Benitez, V., Esteban, R. M., \& Martín-Cabrejas, M. A. (2011). Bioactive phenolic compounds and functional properties of dehydrated bean flours. Food Research International, 44(3), 774780. http://dx.doi.org/10.1016/j.foodres.2011.01.004.

Amarowicz, R., \& Pegg, R. B. (2008). Legumes as a source of natural antioxidants. European Journal of Lipid Science and Technology, 110(10), 865-878. http://dx.doi.org/10.1002/ejlt.200800114.

American Association of Cereal Chemists - AACC. (1995). Determination of Soluble, Insoluble and Total Dietary Fiber in Foods and Food
Products. Approved Methods of the American Association of Cereal Chemists (9th ed., Method 32-07). St. Paul: AACC.

Anonymous. (1981). Tarhana standard (TS 2282). Ankara: Turkish Standards Institute.

Anonymous. (1995). The manual of hunter-lab mini scan XE colorimeter. Virginia: HunterLab Cooperation.

Anonymous. (2005). Gida Mikrobiyolojisi Uygulamaları. Turkey: MERCK.

Anonymous. (2008). Lentil standard (TS 143). Ankara: Turkish Standards Institute.

Asif, M., Rooney, L. W., Ali, R., \& Riaz, M. N. (2013). Application and opportunities of pulses in food system: a review. Critical Reviews in Food Science and Nutrition, 53(11), 1168-1179. http://dx.doi.or g/10.1080/10408398.2011.574804. PMid:24007421.

Association of Official Analytical Chemists - AOAC. (1990). Official methods of analysis (15th ed.). Washington: AOAC.

Association of Official Analytical Chemists - AOAC. (1995). Total, insoluble and soluble dietary fiber in food-enzymatic-gravimetric method MES-TRIS Buffer (16th ed., Method 991.43). Arlington: AOAC.

Bilgiçli, N. (2009). Effect of buckwheat flour on chemical and functional properties of tarhana. Lebensmittel-Wissenschaft + Technologie, 42(2), 514-518. http://dx.doi.org/10.1016/j.lwt.2008.09.006.

Cagindi, O., Aksoylu, Z., Savlak, N. Y., \& Kose, E. (2016). Comparison of physicochemical and functional properties of domestic and commercial tarhana in Turkey. Bulgarian Journal of Agricultural Science, 22(2), 324-330.

Çelik, İ., Işık, F., \& Yılmaz, Y. (2010). Chemical, rheological and sensory properties of tarhana with wheat bran as a functional constituent. Akademik Gıda, 8(3), 11-17.

Celik, I., Isik, F., Simsek, O., \& Gursoy, O. (2005). The effects of the addi- tion of baker's yeast on the functional properties and quality of tarhana, a traditional fermented food. Czech Journal of Food Sciences, 23(5), 190-195. http://dx.doi.org/10.17221/3390-CJFS.

Daglioglu, O. (2000). Tarhana as a traditional Turkish fermented cereal food. Its recipe, production and composition. Die Nahrung, 44(2), 85-88. http://dx.doi.org/10.1002/(SICI)1521-3803(20000301)44:2<85::AIDFOOD85>3.0.CO;2-H. PMid:10795573.

Daglioglu, O., Arici, M., Konyali, M., \& Gumus, T. (2002). Effects of tarhana fermentation and drying methods on the fate of Escherichia coli O157: H7 and Staphylococcus aureus. European Food Research and Technology, 215(6), 515-519. http://dx.doi.org/10.1007/s00217002-0584-0.

Demir, M. K. (2014). Use of quinoa flour in the production of gluten-free tarhana. Food Science and Technology Research, 20(5), 1087-1092. http://dx.doi.org/10.3136/fstr.20.1087.

Derbyshire, E. (2011). The nutritional value of whole pulses and pulse fractions. Pulse foods. Cambridge: Academic Press.

Dewar, D., Pereira, S. P., \& Ciclitira, P. J. (2004). The pathogenesis of coeliac disease. The International Journal of Biochemistry \& Cell 
Biology, 36(1), 17-24. http://dx.doi.org/10.1016/S1357-2725(03)002395. PMid:14592529.

Do, T. A., Vieira, J., Hargreaves, J. M., Mitchell, J. R., \& Wolf, B. (2011). Structural characteristics of cocoa particles and their effect on the viscosity of reduced fat chocolate. Lebensmittel-Wissenschaft + Technologie, 44(4), 1207-1211. http://dx.doi.org/10.1016/j. lwt.2010.10.006.

Dordević, T. M., Šiler-Marinković, S. S., \& Dimitrijević-Branković, S. I. (2010). Effect of fermentation on antioxidant properties of some cereals and pseudo cereals. Food Chemistry, 119(3), 957-963. http:// dx.doi.org/10.1016/j.foodchem.2009.07.049.

Erbaş, M., Certel, M., \& Kemal Uslu, M. (2005). Microbiological and chemical properties of tarhana during fermentation and storage as wet-sensorial properties of Tarhana soup. Lebensmittel-Wissenschaft + Technologie, 38(4), 409-416. http://dx.doi.org/10.1016/j.lwt.2004.06.009.

Gül, T. (2010). Evaluation of stale bread in tarhana production (Master's thesis). Kayseri, Turkey: Erciyes University.

Hayta, M., Alpaslan, M., \& Baysar, A. (2002). Effect of drying methods on functional properties of tarhana: a wheat flour-yoghurt mixture. Journal of Food Science, 67(2), 740-744. http://dx.doi. org/10.1111/j.1365-2621.2002.tb10669.x.

Ibanoğlu, Ş., \& Maskan, M. (2002). Effect of cooking on the drying behav- iour of tarhana dough, a wheat flour-yoghurt mixture. Journal of Food Engineering, 54(2), 119-123. http://dx.doi.org/10.1016/ S0260-8774(01)00192-3.

Ibanoğlu, S., Ibanoğlu, E., \& Ainsworth, P. (1999). Effect of different ingre- dients on the fermentation activity in tarhana. Food Chemistry, 64(1), 103-106. http://dx.doi.org/10.1016/S0308-8146(98)00071-5.

Isik, F., \& Yapar, A. (2014). Fatty acid composition and sensory properties of tarhanas prepared by processed tomato and paprika waste materials. Journal of Food Processing and Preservation, 38(1), 607-614. http://dx.doi.org/10.1111/jfpp.12010.

Isik, F., \& Yapar, A. (2017). Effect of tomato seed supplementation on chemical and nutritional properties of tarhana. Journal of Food Measurement and Characterization, 11(2), 667-674. http://dx.doi. org/10.1007/s11694-016-9436-7.

Jnawali, P., Kumar, V., \& Tanwar, B. (2016). Celiac disease: overview and considerations for development of gluten-free foods. Food Science and Human Wellness, 5(4), 169-176. http://dx.doi.org/10.1016/j. fshw.2016.09.003.

Koca, I., Yilmaz, V. A., \& Tekguler, B. (2017). A gluten-free food: tarhana with chestnut. In: Proceedings of the VI International Chestnut Symposium (pp. 195-202). Turkey: ISHS.

Köse, E., \& Çağındı, Ö. (2002). An investigation into the use of different fl ours in tarhana. International Journal of Food Science \& Technology, 37(2), 219-222. http://dx.doi.org/10.1046/j.1365-2621.2002.00559.x.

Levent, H. (2019). Physical, chemical and sensory evaluation of gluten-free tarhana with legume hulls and flours. Quality Assurance and Safety of Crops \& Foods, 11(4), 1-10. http://dx.doi.org/10.3920/QAS2018.1538.

Magalhães, S. C., Taveira, M., Cabrita, A. R., Fonseca, A. J., Valentão, P., \& Andrade, P. B. (2017). European marketable grain legume seeds: further insight into phenolic compounds profiles. Food Chemistry, 215, 177-184. http://dx.doi.org/10.1016/j.foodchem.2016.07.152. PMid:27542465.
O'Callaghan, Y. C., Shevade, A. V., Guinee, T. P., O'Connor, T. P., \& O'Brien, N. M. (2019). Comparison of the nutritional composition of experimental fermented milk: wheat bulgur blends and commercially available kishk and tarhana products. Food Chemistry, 278, 110-118. http://dx.doi.org/10.1016/j.foodchem.2018.11.026. PMid:30583351.

Oomah, B. D., Caspar, F., Malcolmson, L. J., \& Bellido, A. S. (2011). Phenolics and antioxidant activity of lentil and pea hulls. Food Research International, 44(1), 436-441. http://dx.doi.org/10.1016/j. foodres.2010.09.027.

Ozbek, N., \& Ozcan, M. (2017). Elemental analysis of tarhana by microwave induced plasma atomic emission spectrometry. Analytical Letters, 50(13), 2139-2146. http://dx.doi.org/10.1080/00032719.20 16.1266362 .

Ozdemir, N., Simsek, O., Temiz, H., \& Con, A. H. (2019). The effect of fermentation time on the volatile aromatic profile of tarhana dough. Food Science \& Technology International, 25(3), 212-222. http://dx.doi.org/10.1177/1082013218815325. PMid:30509133.

Pietzak, M. M., Catassi, C., Drago, S., Fornaroli, F., \& Fasano, A. (2001). Celiac disease: going against the grains. Nutrition in Clinical Practice, 16(6), 335-344. http://dx.doi.org/10.1177/088453360101600606.

Salameh, C., Scher, J., Petit, J., Gaiani, C., Hosri, C., \& Banon, S. (2016). Physico-chemical and rheological properties of Lebanese kishk powder, a dried fermented milk-cereal mixture. Powder Technology, 292, 307-313. http://dx.doi.org/10.1016/j.powtec.2016.01.040.

Sengun, I. Y., Nielsen, D. S., Karapinar, M., \& Jakobsen, M. (2009). Identification of lactic acid bacteria isolated from Tarhana, a traditional Turkish fermented food. International Journal of Food Microbiology, 135(2), 105-111. http://dx.doi.org/10.1016/j.ijfoodmicro.2009.07.033. PMid:19703719.

Settanni, L., Tanguler, H., Moschetti, G., Reale, S., Gargano, V., \& Erten, H. (2011). Evolution of fermenting microbiota in tarhana produced under controlled technological conditions. Food Microbiology, 28(7), 1367-1373. http://dx.doi.org/10.1016/j.fm.2011.06.008. PMid:21839387.

Singleton, V. L., Orthofer, R., \& Lamuela-Raventos, R. M. (1999). Analysis of total phenols and other oxidation substrates and antioxidants by means of Folin-Ciocalteu reagent. Methods in Enzymology, 299, 152-178. http://dx.doi.org/10.1016/S0076-6879(99)99017-1.

Temiz, A., \& Yllmazer, N. (1998). Identification of lactic acid bacteria isolated from tarhana during fermentation. Acta Alimentaria, 27, 277-291.

Thaipong, K., Boonprakob, U., Crosby, K., Cisneros-Zevallos, L., \& Hawkins Byrne, D. (2006). Comparison of ABTS, DPPH, FRAP, and ORAC assays for estimating antioxidant activity from Guava fruit extracts. Journal of Food Composition and Analysis, 19(6-7), 669-675. http://dx.doi.org/10.1016/j.jfca.2006.01.003.

Wang, N. (2008). Effect of variety and crude protein content on dehulling quality and on the resulting chemical composition of red lentil (Lens culinaris). Journal of the Science of Food and Agriculture, 88(5), 885-890. http://dx.doi.org/10.1002/jsfa.3165.

Yildirim, Z., \& Ercan, R. (2004). The effects of extrusion cooking conditions on solubility and water absorbtion of tarhana produced with different types of wheat flour. JAS Tarim Bilimleri Dergisi, 10(4), 428-434. 